\title{
Unprecedented Zeolite-Like Framework Topology Constructed from Cages with 3-Rings in a Barium Oxonitridophosphate
}

\author{
Stefan J. Sedlmaier, Markus Döblinger, Oliver Oeckler, Johannes Weber, Jörn Schmedt auf der Günne, \\ and Wolfgang Schnick*
}

Ludwig-Maximilians-Universität München, Department Chemie, Butenandtstrasse 5-13 (D), D-81377 Munich, Germany

Supporting Information

ABSTRACT: A novel oxonitridophosphate, $\mathrm{Ba}_{19} \mathrm{P}_{36} \mathrm{O}_{6+x} \mathrm{~N}_{66-x} \mathrm{Cl}_{8+x}(x \approx 4.54)$, has been synthesized by heating a multicomponent reactant mixture consisting of phosphoryl triamide $\mathrm{OP}\left(\mathrm{NH}_{2}\right)_{3}$, thiophosphoryl triamide $\mathrm{SP}\left(\mathrm{NH}_{2}\right)_{3}, \mathrm{BaS}$, and $\mathrm{NH}_{4} \mathrm{Cl}$ enclosed in an evacuated and sealed silica glass ampule up to $750{ }^{\circ} \mathrm{C}$. Despite the presence of side phases, the crystal structure was elucidated $\mathrm{ab}$ initio from high-resolution synchrotron powder diffraction data $(\lambda=39.998 \mathrm{pm})$ applying the charge flipping algorithm supported by independent symmetry information derived from electron diffraction (ED) and scanning transmission electron microscopy (STEM). The compound crystallizes in the cubic space group $F m \overline{3} c$ (no. 226) with $a=2685.41(3) \mathrm{pm}$ and $Z=8$. As confirmed by Rietveld refinement, the structure comprises all-side vertex sharing $\mathrm{P}(\mathrm{O}, \mathrm{N})_{4}$ tetrahedra forming slightly distorted $3^{8} 4^{6} 8^{12}$ cages representing a novel composite building unit $(\mathrm{CBU})$. Interlinked through their 4-rings and additional 3-rings, the cages build up a 3D network with a framework density FD $=14.87 \mathrm{~T} /$ $1000 \AA^{3}$ and a 3D 8-ring channel system. $\mathrm{Ba}^{2+}$ and $\mathrm{Cl}^{-}$as extra-framework ions are located

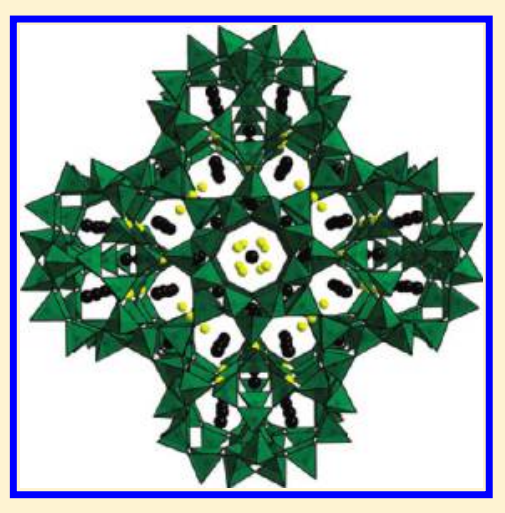
within the cages and channels of the framework. The structural model is corroborated by ${ }^{31} \mathrm{P}$ double-quantum (DQ) / single-quantum (SQ) and triple-quantum (TQ) / single-quantum (SQ) $2 \mathrm{D}$ correlation MAS NMR spectroscopy. According to ${ }^{31} \mathrm{P}\left\{{ }^{1} \mathrm{H}\right\} \mathrm{C}-\mathrm{REDOR}$ NMR measurements, the $\mathrm{H}$ content is less than one $\mathrm{H}$ atom per unit cell.

\section{INTRODUCTION}

Classical zeolites, such as aluminosilicates and aluminophosphates, are well-established in fundamental industrial processes, e.g., substance separation, air and water conditioning, or catalysis. As they have the potential for further applications in future technologies (e.g., sensors, electronic, or optical systems), inorganic open-framework materials emerged as a research area with a multitude of compound classes in the last decades. In addition to diverse metal phosphates, germanates, and borates, there are sulfates, arsenates, or phosphonates as well as organic-inorganic hybrid compounds with porous networks. ${ }^{1,2}$ However, many microporous structures are thermally and chemically not sufficiently stable to make their way toward advanced materials. Consequently, it is worthwhile to synthesize novel open-framework materials that exhibit three-dimensional, rigid framework structures based on vertex-sharing tetrahedra. Since the discovery of the aluminophosphates by Flanigen et al. ${ }^{3}$ in the 1980 s, it has been attempted with great creativity and effort to access new stable frameworks with different pore sizes and shapes combined with varying chemical and physical properties. Different synthesis conditions (temperature, reaction time, $\mathrm{pH}$ ), many different structure-directing agents (SDA), as well as a broad spectrum of solvents, including ionic liquids, were employed. The fluoride route ${ }^{4}$ has been utilized, and other tetrahedra centers (e.g., B, Ga, $\mathrm{Zn}$ ) were included, resulting in new zeotypes in compound classes like silicoaluminophosphates (SAPOs) and metal-containing versions (e.g., MeAPO, MeAPSO) thereof. ${ }^{2,5}$ Thus, the field of zeolite chemistry seems quite mature which means that the search for new framework types becomes increasingly challenging.

The exchange of oxygen by nitrogen in the anionic substructure is an innovative but rarely realized expansion of zeolite chemistry. Nitrido-zeolites promise beneficial chemical and physical properties (e.g., higher thermal stability or adjustable acidity/basicity) and a huge structural diversity. As compared with oxygen, nitrogen atoms are more common in three-binding situations, and they provide more flexibility as bridging atoms in networks by occasionally realizing smaller angles $\mathrm{T}-\mathrm{X}-\mathrm{T}(\mathrm{X}=$ $\mathrm{O}, \mathrm{N}$ ). Consequently, both large rings as well as rare 3-rings can be stabilized so that novel zeolite-like frameworks become possible.

This nitride concept became reality in (oxo-)nitridosilicates and (oxo-)nitridophosphates. After the proof of concept with nitridosodalites ${ }^{6}$ and related oxonitridosodalites, ${ }^{7}$ the benefits of nitrogen in zeolite-like framework structures have been demonstrated only for very few examples. Besides a zeolite-like $\mathrm{Si}-\mathrm{N}$ framework in $\mathrm{Ba}_{2} \mathrm{Nd}_{7} \mathrm{Si}_{11} \mathrm{~N}_{23}$ with a notable thermal stability up to $1600{ }^{\circ} \mathrm{C}$, ${ }^{8}$ the flexibility of $\mathrm{N}$ bridging resulted in $\mathrm{Li}_{x} \mathrm{H}_{12-x-y+z^{-}}$ $\left[\mathrm{P}_{12} \mathrm{O}_{y} \mathrm{~N}_{24-y}\right] \mathrm{X}_{z}$ for $\mathrm{X}=\mathrm{Cl}, \mathrm{Br}$ with a new zeolite topology, namely, NPO (nitridophosphate one). ${ }^{9}$ The typical (ring-)strain

Received: March 20, 2011

Published: June 24, 2011 
in such an extended 3-ring system could only be realized with that framework type material and the related nitridic compounds $\mathrm{Ba}_{3} \mathrm{Si}_{3} \mathrm{~N}_{5} \mathrm{OCl}, \mathrm{Ba}_{3} \mathrm{Ta}_{3} \mathrm{~N}_{6} \mathrm{Cl}, \mathrm{Ba}_{15} \mathrm{Ta}_{15} \mathrm{~N}_{33} \mathrm{Cl}_{4}$, and $\mathrm{Ba}_{6} \mathrm{Si}_{6} \mathrm{~N}_{10} \mathrm{O}_{2^{-}}$ $\left(\mathrm{CN}_{2}\right)$ so far. ${ }^{10,11}$ The clathrate $\mathrm{P}_{4} \mathrm{~N}_{4}(\mathrm{NH})_{4}\left(\mathrm{NH}_{3}\right)^{12}$ with its $4^{2} 8^{4}$ cages encapsulating ammonia molecules could be synthesized because rather small angles $\mathrm{T}-\mathrm{X}-\mathrm{T}$ can be realized in phosphorus nitride networks. Taking into account the high thermal and chemical stability and further proposed applications like, e.g., the clathrate as gas storage or membrane reactor material, ${ }^{13}$ these examples show the potential of the nitride chemistry in the field of open-framework structures.

In this contribution, we describe the synthesis and structure elucidation of the oxonitridophosphate $\mathrm{Ba}_{19} \mathrm{P}_{36} \mathrm{O}_{6+x} \mathrm{~N}_{66-x} \mathrm{Cl}_{8+x}$ $(x \approx 4.54)$ which exhibits a novel zeolite-like framework topology involving a new composite building $u$ nit (CBU).

\section{EXPERIMENTAL SECTION}

Synthesis of $\mathrm{Ba}_{19} \mathrm{P}_{36} \mathrm{O}_{6+x} \mathrm{~N}_{66-x} \mathrm{Cl}_{8+x}(x \approx 4.54)$. Phosphoryl triamide $\mathrm{OP}\left(\mathrm{NH}_{2}\right)_{3}$ and thiophosphoryl triamide $\mathrm{SP}\left(\mathrm{NH}_{2}\right)_{3}$ were synthesized according to the literature ${ }^{14,15}$ similar to procedures described by Correll. ${ }^{16}$ First, $10-20 \mathrm{~mL}$ of freshly distilled $\mathrm{POCl}_{3}$ (Acros Organics, Geel, Belgium, 99\%) and $\mathrm{PSCl}_{3}$ (Acros Organics, 98\%), respectively, were added directly and slowly to liquid ammonia in a flame-dried Schlenk-type $1 \mathrm{~L}$ flask. In the second step, the elimination of $\mathrm{NH}_{4} \mathrm{Cl}$ from the products was carried out performing a Soxhlet extraction with distilled $\mathrm{Et}_{2} \mathrm{NH}$ (Grüssing $\mathrm{GmbH}$, Filsum, Germany, $99 \%$ ) in dry $\mathrm{CH}_{2} \mathrm{Cl}_{2}$ for three days. After drying in vacuo, $\mathrm{OP}\left(\mathrm{NH}_{2}\right)_{3}$ and $\mathrm{SP}\left(\mathrm{NH}_{2}\right)_{3}$ are available as starting materials in the form of colorless, water-sensitive powders. Their purity was verified with powder X-ray diffraction.

$\mathrm{Ba}_{19} \mathrm{P}_{36} \mathrm{O}_{6+x} \mathrm{~N}_{66-x} \mathrm{Cl}_{8+x}(x \approx 4.54)$ has been synthesized employing a multicomponent reactant system. In a typical procedure, $\mathrm{BaS}(57.9 \mathrm{mg}$, $0.342 \mathrm{mmol}$; Sigma-Aldrich, 99.9\%), $\mathrm{OP}\left(\mathrm{NH}_{2}\right)_{3}(10.3 \mathrm{mg}, 0.108 \mathrm{mmol})$, $\mathrm{SP}\left(\mathrm{NH}_{2}\right)_{3}(60.0 \mathrm{mg}, 0.540 \mathrm{mmol})$, and $\mathrm{NH}_{4} \mathrm{Cl}(23.1 \mathrm{mg}, 0.432 \mathrm{mmol}$; Fluka, puriss. p.a.) were thoroughly mixed and ground in a glovebox (MBraun, Garching, Germany) and subsequently transferred into a silica glass ampule (wall thickness $2 \mathrm{~mm}$, inner diameter $11 \mathrm{~mm}$ ). The evacuated and sealed ampule (length around $110 \mathrm{~mm}$ ) was heated to 200 and $750{ }^{\circ} \mathrm{C}$ in a tube furnace with dwell times of 12 and $48 \mathrm{~h}$ (heating rate, $1 \mathrm{~K} \mathrm{~min}^{-1}$; cooling rate, $0.25 \mathrm{~K} \mathrm{~min}^{-1}$ ), respectively. The emerging condensation products $\mathrm{NH}_{3}$ and $\mathrm{H}_{2} \mathrm{~S}$ partially are deposited as $\left(\mathrm{NH}_{4}\right)_{2} \mathrm{~S}$ together with excess $\mathrm{NH}_{4} \mathrm{Cl}$ at the cooler zones of the ampule. After breaking the ampules, the samples were washed with water and DMF to remove the remaining $\mathrm{NH}_{4} \mathrm{Cl}$ and $\mathrm{BaS} . \mathrm{Ba}_{19} \mathrm{P}_{36} \mathrm{O}_{6+x} \mathrm{~N}_{66-x} \mathrm{Cl}_{8+x}$ $(x \approx 4.54)$ was obtained as a colorless, water- and air-resistant, microcrystalline powder containing small amounts of various crystalline and amorphous byproducts that could not be removed by washing. Besides the starting materials named above, $\mathrm{BaCl}_{2}$ or other $\mathrm{P} / \mathrm{N} / \mathrm{O} / \mathrm{Cl}$ containing chemicals like $\mathrm{P}\left(\mathrm{NH}_{2}\right)_{4} \mathrm{Cl}_{1}{ }^{17}\left[\mathrm{PN}(\mathrm{NH})_{2}\right]_{3}{ }^{18}$ or $\left(\mathrm{NH}_{2}\right)_{2}(\mathrm{O})$ $\mathrm{PNP}\left(\mathrm{NH}_{2}\right)_{3}{ }^{19}$ can also be used in the synthesis. The purest product, however, was obtained with the combination named at the beginning of the paragraph.

Powder X-ray Diffraction (PXRD), Structure Solution, and Rietveld Refinement. High-resolution synchrotron PXRD data of different samples were collected at $298 \mathrm{~K}$ at beamline ID31 (ESRF, Grenoble, France), using a Debye-Scherrer setup (with spinning glass capillaries, $1 \mathrm{~mm}$ diameter $)$ with monochromatic radiation $(\lambda=39.998 \mathrm{pm})$ and a nine-crystal multianalyzer detector. ${ }^{20}$

Extraction of the peak positions, pattern indexing, structure solution, Fourier calculations, and Rietveld refinements was carried out with the TOPAS package. ${ }^{21}$ By evaluation of all measured patterns, the reflections of $\mathrm{Ba}_{19} \mathrm{P}_{36} \mathrm{O}_{6+x} \mathrm{~N}_{66-x} \mathrm{Cl}_{8+x}(x \approx 4.54)$ have been identified

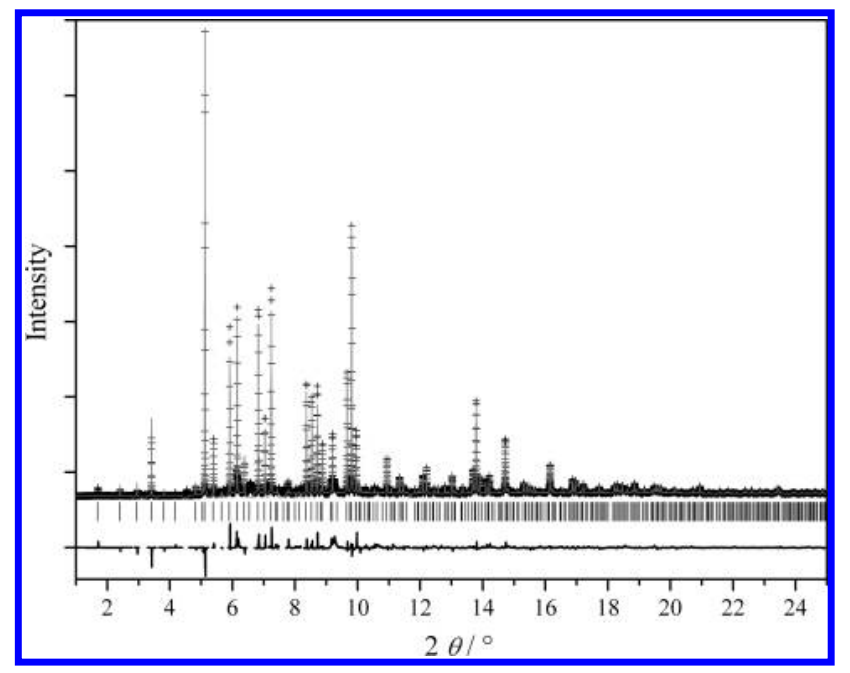

Figure 1. Observed (crosses) and calculated (gray line) powder diffraction pattern as well as difference profile of the Rietveld refinement. Peak positions are marked by vertical lines. Regions with impurity reflections have been excluded (wherever applicable, see text).

unequivocally. Indexing by the SVD method ${ }^{22}$ yielded cubic unit cells, either $c P$ with $a=1341.62 \mathrm{pm}$ or-taking into account some additional weak reflections $-c$ F with $a=2683.24 \mathrm{pm}$.

For the further process, the pattern with the lowest amount of impurity reflections was selected. After evaluation of scanning transmission electron microscopy (STEM) images recorded in high-angle annular dark field (HAAF) mode and selected-area electron diffraction (SAED) patterns (see below), the space group $F m \overline{3} c$ (no. 226) was unambiguously identified. The structure solution succeeded $a b$ initio using the charge flipping algorithm ${ }^{23}$ and subsequent difference Fourier syntheses and placing bridging atoms at reasonable positions. Rietveld refinement of the final structure model was carried out applying the fundamental parameters approach (direct convolution of source emission profiles, instrument contributions, and crystallite size and microstrain effects). ${ }^{24}$ The preferred orientation of the crystallites was described with fourth-order spherical harmonics. As far as possible, regions containing parasitic reflections from byproducts have been excluded. Remaining misfits indicated by the difference profile originate from regions where impurity reflections are overlapping with those of the target compound (cf. Figure 1). Overall displacement parameters have been used for $\mathrm{Cl}^{-}$and $\mathrm{N} / \mathrm{O}$, respectively. A common $\mathrm{O} / \mathrm{N}$ ratio on all bridging atom positions was derived by constraining the occupancy to be $100 \%$ and guaranteeing charge neutrality by taking the partially occupied $\mathrm{Cl}^{-}$positions into account. For an optimized tetrahedral geometry, distance constraints (165 pm for $\mathrm{P}-(\mathrm{N} / \mathrm{O}), 269 \mathrm{pm}$ for $(\mathrm{N} / \mathrm{O})-(\mathrm{N} / \mathrm{O}))$ have been included. Furthermore, absorption as well as a cylindrical $2 \theta$ correction $^{25}$ was applied. Crystallographic data and further details of the data collection are summarized in Table 1. Table 2 shows the positional and displacement parameters for all atoms. Due to a step width of $0.002^{\circ} 2 \theta$, severe serial correlation occurs. Consequently, the estimated standard derivations are underestimated. ${ }^{26,27}$ The Rietveld fit is displayed in Figure 1. Further details of the crystal structure investigation may be obtained from Fachinformationszentrum Karlsruhe, 76344 Eggenstein-Leopoldshafen, Germany (fax: (+49) 7247808-666; e-mail: crysdata(@)fiz-karlsruhe.de, http://www.fiz-karlsruhe. de/request_for_deposited_data.html) on quoting the depository number CSD-422769.

Electron Microscopy. SAED and STEM measurements were carried out on a transmission electron microscope FEI Titan 80-300 equipped with a field emission gun operating at $300 \mathrm{kV}$. STEM-HAADF 
Table 1. Crystallographic Data for $\mathrm{Ba}_{19} \mathrm{P}_{36} \mathrm{O}_{6+x} \mathrm{~N}_{66-x} \mathrm{Cl}_{8+x}$ $(x \approx 4.54)$ in $F m \overline{3} c$ (esd's in Parentheses)

crystal structure data

\begin{tabular}{|c|c|}
\hline formula & $\mathrm{Ba}_{19} \mathrm{P}_{36} \mathrm{O}_{10.54} \mathrm{~N}_{61.46} \mathrm{Cl}_{12.54}$ \\
\hline formula mass $/ \mathrm{g} \mathrm{mol}^{-1}$ & 5198.4143 \\
\hline crystal system & cubic \\
\hline space group & $F m \overline{3} c($ no. 226$)$ \\
\hline cell parameter/pm & $a=2685.41(3)$ \\
\hline cell volume $/ 10^{6} \mathrm{pm}^{3}$ & $V=19365.6(6)$ \\
\hline formula units/cell & $Z=8$ \\
\hline $\mathrm{X}$-ray density $/ \mathrm{g} \cdot \mathrm{cm}^{-3}$ & $\rho=3.566(2)$ \\
\hline $\mathrm{FD} / \mathrm{T} 10^{-3} \AA^{-3}$ & 14.87 \\
\hline \multicolumn{2}{|l|}{ data collection } \\
\hline \multirow[t]{2}{*}{ radiation } & synchrotron (beamline ID31, \\
\hline & ESRF, Grenoble), $\lambda=39.998 \mathrm{pm}$ \\
\hline temperature/K & $298(2)$ \\
\hline $2 \theta$ range $/^{\circ}$ & $1.0-45.5$ \\
\hline data points & 22000 \\
\hline number of observed reflections & 3211 \\
\hline \multicolumn{2}{|l|}{ structure refinement } \\
\hline method of refinement & fundamental parameters model ${ }^{24}$ \\
\hline program used & TOPAS-Academic $4.1^{21}$ \\
\hline atomic parameters & 27 \\
\hline profile parameters & 9 \\
\hline background function/parameters & shifted Chebyshev/40 \\
\hline other parameters & 4 \\
\hline restraints & 3 \\
\hline constraints & 15 \\
\hline fwhm $\left(\right.$ reflection at $\left.3.424^{\circ} 2 \theta\right) /{ }^{\circ}$ & 0.008 \\
\hline \multirow{4}{*}{$R$ indices } & $\chi^{2}=5.172$ \\
\hline & $R_{\mathrm{p}}=0.0906$ \\
\hline & $\mathrm{w} R_{\mathrm{p}}=0.1215$ \\
\hline & $R_{\text {Bragg }}=0.0770$ \\
\hline
\end{tabular}

images were recorded using a Fischione model $3000 \mathrm{ADF}$ detector, and diffraction patterns were recorded with a Gatan UltraScan $1000(2 \mathrm{k} \times$ $2 \mathrm{k}$ ) CCD camera. The samples were finely dispersed in ethanol by sonication, and a small amount of the suspension was subsequently dispersed on copper grids coated with holey carbon film. The grids were mounted on a double tilt holder with a maximum tilt angle of $30^{\circ}$. Simulations of electron diffraction patterns were carried out with the online version of the EMS program package (Electron Microscopy Image Simulation). ${ }^{28}$

Scanning electron microscopy (SEM) and energy dispersive X-ray analysis (EDX) were performed using a JSM-6500F electron microscope (JEOL Ltd., Tokyo, Japan) with a field emission source equipped with an EDX detector model 7418 (Oxford Instruments, Oxfordshire, UK). Powders were placed on a brass sample carrier fixed with self-adhesive carbon plates (Plano GmbH, Wetzlar, Germany). The samples were sputtered with carbon (sputter device: BAL-TEC MED 020, BAL-TEC AG, Balzers, Netherlands). EDX data collection and evaluation was carried out with the aid of the INCA program package.

Solid-State MAS (Magic Angle Spinning) NMR (Nuclear Magnetic Resonance) Methods. ${ }^{1} \mathrm{H}$ and ${ }^{31} \mathrm{P}$ solid-state MAS NMR spectra of $\mathrm{Ba}_{19} \mathrm{P}_{36} \mathrm{O}_{6+x} \mathrm{~N}_{66-x} \mathrm{Cl}_{8+x}(x \approx 4.54)$ were recorded at ambient temperature on a Bruker Avance III spectrometer with an $11.75 \mathrm{~T}$ magnet. The powdered samples were contained in $\mathrm{ZrO}_{2}$ rotors with outer diameters of 2.5 or $1.3 \mathrm{~mm}$ which were mounted in commercial MAS probes (Bruker). The rotors were spun at rotation frequencies $v_{\text {MAS }}$ between 8 and $20(2.5 \mathrm{~mm})$ and $50 \mathrm{kHz}(1.3 \mathrm{~mm})$, respectively. Chemical shifts are given relative to the respective reference compounds $\left({ }^{1} \mathrm{H}: 1 \%\right.$ tetramethylsilane (TMS) in $\mathrm{CDCl}_{3} ;{ }^{31} \mathrm{P}: 85 \% \mathrm{H}_{3} \mathrm{PO}_{4}, \mathrm{~T}=$ $298 \mathrm{~K}$ ) as external standards. The calibration of the spectrometer was done with TMS under MAS conditions using the unified scale $\Xi$ and the chemical shift definitions in the literature. ${ }^{29}$ Quantitative ${ }^{1} \mathrm{H}$ spectra and ${ }^{31} \mathrm{P}$ spectra were obtained by a rotor-synchronized spin-echo sequence at $v_{\text {MAS }}=20 \mathrm{kHz}$ with a repetition delay of $32 \mathrm{~s}$ in the case of ${ }^{1} \mathrm{H}$ and of $1500 \mathrm{~s}$ in the case of ${ }^{31} \mathrm{P}$.

$\mathrm{A}^{31} \mathrm{P} 2 \mathrm{D}$ double-quantum (DQ) single-quantum (SQ) correlation MAS NMR spesctrum was obtained using PostC $7^{30}$ with a conversion period of $0.8 \mathrm{~ms}$ and rotor-synchronized data sampling of the indirect dimension. A ${ }^{31} \mathrm{P} 2 \mathrm{D}$ triple-quantum (TQ) single-quantum (SQ) correlation MAS NMR spectrum $^{31}$ was obtained with a conversion period of $1.6 \mathrm{~ms}$ and rotor-synchronized data sampling of the indirect dimension. A ${ }^{31} \mathrm{P}\left\{{ }^{1} \mathrm{H}\right\}$ PostC $3{ }_{3}^{1}-\mathrm{REDOR}^{32}$ curve was recorded to determine the effective dipolar coupling constant and estimate limits for the interatomic $\mathrm{P}-\mathrm{H}$ distances. The experimental data are compared with simulated curves for different effective dipolar couplings on the universal dephasing scale. ${ }^{33}$

\section{RESULTS AND DISCUSSION}

Synthesis. Oxonitridophosphates are isolobal and isoelectronic with silicates. However, the variety of silicate structures is far from being emulated with $\mathrm{P} / \mathrm{O} / \mathrm{N}$ chemistry. This suggests great potential, but the reaction and crystallization temperatures are often close to the decomposition temperature of the starting materials (e.g., $\mathrm{PON}$ and $\mathrm{P}_{3} \mathrm{~N}_{5}$ decompose from $800^{\circ} \mathrm{C}$ ) or the (oxo-)nitridophosphate phases themselves. ${ }^{34}$ To prevent this decomposition, ${ }^{35}$ high-pressure synthesis ${ }^{36}$ has been used for most known $\mathrm{P} /(\mathrm{O}) / \mathrm{N}$ phases. However, high pressure obviously favors materials with a high density and is not the method of choice to obtain porous open-framework oxonitridophosphates. Therefore, suitable starting materials and reaction conditions are required, e.g., $\mathrm{P} /(\mathrm{O}) / \mathrm{N} / \mathrm{H}$-containing molecular compounds in the closed system of evacuated silica glass ampules in the presence of metal salts and $\mathrm{NH}_{4} \mathrm{X}(\mathrm{X}=$ halogen $)$ as mineralizer. $6,7,9$

Besides other starting materials like $\left(\mathrm{NH}_{2}\right)_{2}(\mathrm{O}) \mathrm{PNP}\left(\mathrm{NH}_{2}\right)_{3}{ }^{19}$ a convenient approach for synthesis of oxonitridophosphate frameworks is the joint thermal condensation of phosphoryl triamide $\mathrm{OP}\left(\mathrm{NH}_{2}\right)_{3}$ and thiophosphoryl triamide $\mathrm{SP}\left(\mathrm{NH}_{2}\right)_{3}$. While the latter allows a controlled addition of oxygen, the ammonia partial pressure emerging during the condensation in a closed system offers the conditions necessary for the crystallization process which can further be adjusted by adding a respective amount of $\mathrm{NH}_{4} \mathrm{X}(\mathrm{X}=$ halogen $)$. The metal salts act as structure-stabilizing agents.

In the case of $\mathrm{Ba}_{19} \mathrm{P}_{36} \mathrm{O}_{6+x} \mathrm{~N}_{66-x} \mathrm{Cl}_{8+x}(x \approx 4.54)$, the combination of $\mathrm{BaS}, \mathrm{OP}\left(\mathrm{NH}_{2}\right)_{3}, \mathrm{SP}\left(\mathrm{NH}_{2}\right)_{3}$, and $\mathrm{NH}_{4} \mathrm{Cl}$ (cf. Experimental Section) led to the best result after a series of experiments with different starting materials (e.g., $\mathrm{BaCl}_{2}$ or $\left.\mathrm{P}\left(\mathrm{NH}_{2}\right)_{4} \mathrm{Cl}\right)$ in different molar ratios, and different temperature programs had been carried out to optimize the yield of the title compound. Although $\mathrm{Ba}_{19} \mathrm{P}_{36} \mathrm{O}_{6+x} \mathrm{~N}_{66-x} \mathrm{Cl}_{8+x}(x \approx 4.54)$ is routinely obtained by different approaches, it turned out that the reactant system is very sensitive concerning the appearance and type of impurities. This is an intrinsic problem as at least four starting materials react at high temperatures. Many parameters 
Table 2. Atomic Coordinates, Wyckoff Symbols, and Isotropic Displacement Parameters $B_{\text {iso }} / \AA^{2}$ for the $A$ toms in $\mathrm{Ba}_{19} \mathrm{P}_{36} \mathrm{O}_{6+x^{-}}$ $\mathrm{N}_{66-x} \mathrm{Cl}_{8+x}(x \approx 4.54)$ in $\mathrm{Fm} \overline{3} c$ (esd's in Parentheses Are Underestimated Due to Severe Serial Correlation)

\begin{tabular}{|c|c|c|c|c|c|c|}
\hline atom & Wyckoff symbol & $x$ & $y$ & $z$ & occupancy & $B_{\text {iso }}$ \\
\hline $\mathrm{Ba}(1)$ & $48 f$ & $0.1055(1)$ & $1 / 4$ & $1 / 4$ & 1 & $2.28(5)$ \\
\hline $\mathrm{Ba}(2)$ & $96 i$ & 0 & $0.1402(1)$ & $0.1334(1)$ & 1 & $3.06(5)$ \\
\hline $\mathrm{Ba}(3)$ & $8 b$ & 0 & 0 & 0 & 1 & $1.56(13)$ \\
\hline $\mathrm{P}(1)$ & $192 j$ & $0.6238(2)$ & $0.6182(1)$ & $0.6962(1)$ & 1 & $0.58(8)$ \\
\hline $\mathrm{P}(2)$ & $96 h$ & $1 / 4$ & $0.9441(1)$ & $y$ & 1 & $1.81(16)$ \\
\hline $\mathrm{Cl}(1)$ & $64 g$ & $0.0689(2)$ & $x$ & $x$ & 1 & \multirow{2}{*}{$1.14(11)$} \\
\hline $\mathrm{Cl}(2)$ & $96 i$ & $0.2969(5)$ & 0 & $0.7593(7)$ & $0.378(5)$ & \\
\hline $\mathrm{N}(1)$ & \multirow[b]{2}{*}{$96 i$} & \multirow[b]{2}{*}{0} & \multirow[b]{2}{*}{$0.9331(2)$} & \multirow[b]{2}{*}{$0.7337(2)$} & $0.854(5)$ & \multirow{8}{*}{$2.56(20)$} \\
\hline $\mathrm{O}(1)$ & & & & & $0.146(5)$ & \\
\hline $\mathrm{N}(2)$ & & & & & $0.854(5)$ & \\
\hline $\mathrm{O}(2)$ & $192 j$ & $0.3334(2)$ & $0.3291(2)$ & $0.4025(2)$ & $0.146(5)$ & \\
\hline $\mathrm{N}(3)$ & \multirow[b]{2}{*}{$96 h$} & \multirow[b]{2}{*}{$1 / 4$} & \multirow{2}{*}{$0.8591(2)$} & \multirow[b]{2}{*}{$y$} & $0.854(5)$ & \\
\hline $\mathrm{O}(3)$ & & & & & $0.146(5)$ & \\
\hline $\mathrm{N}(4)$ & \multirow{2}{*}{$192 j$} & \multirow{2}{*}{$0.5840(2)$} & \multirow{2}{*}{$0.5712(2)$} & \multirow{2}{*}{$0.6984(2)$} & $0.854(5)$ & \\
\hline $\mathrm{O}(4)$ & & & & & $0.146(5)$ & \\
\hline
\end{tabular}

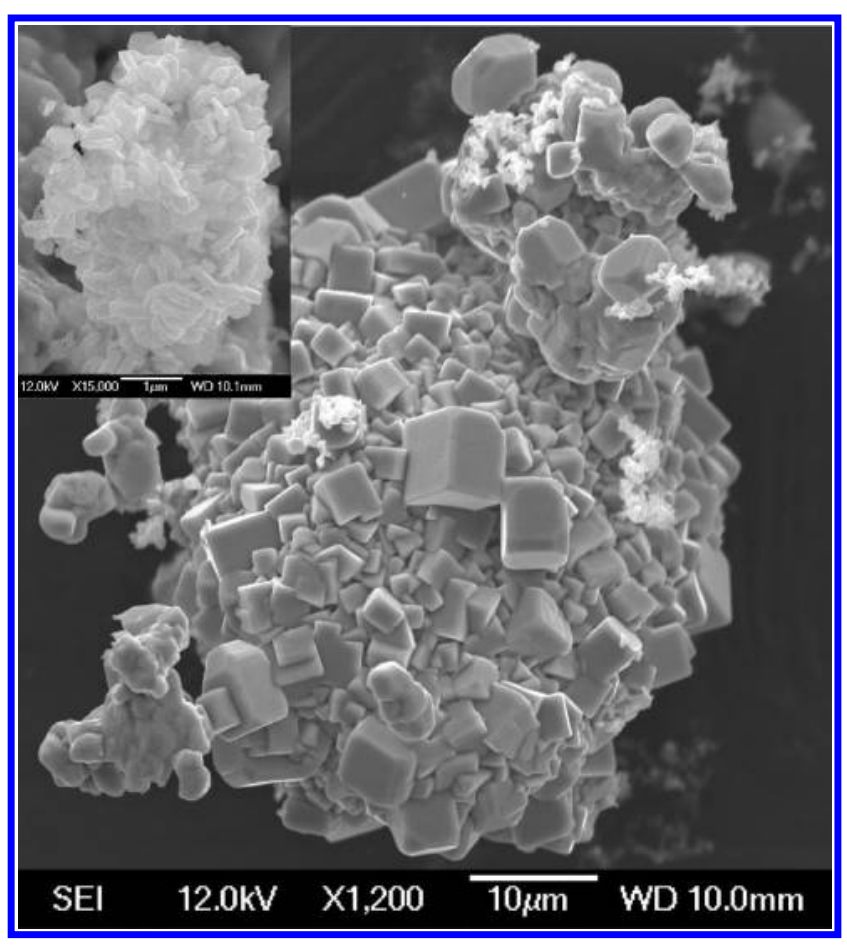

Figure 2. SEM images of $\mathrm{Ba}_{19} \mathrm{P}_{36} \mathrm{O}_{6+x} \mathrm{~N}_{66-x} \mathrm{Cl}_{8+x}(x \approx 4.54)$ as cuboidal microcrystals and the $\mathrm{Ba} / \mathrm{P} / \mathrm{O} / \mathrm{N}$ side phase as nanometersized platelets (bright areas in the big image and small SEM image).

such as the $\mathrm{NH}_{3}$ partial pressure and the amount of $\mathrm{Cl}^{-}$ions are simultaneously affected and cannot be fully controlled, so far impeding the phase-pure synthesis of $\mathrm{Ba}_{19} \mathrm{P}_{36} \mathrm{O}_{6+x} \mathrm{~N}_{66-x} \mathrm{Cl}_{8+x}$ $(x \approx 4.54)$. However, the title compound is typically obtained as the most prominent crystalline phase with more than $90 \%$ yield (estimated from the intensity ratio of strongest Bragg peaks of the title compound and side phase(s)). Figure 2 shows the title compound as cuboidal microcrystals with a mean edge length of 3-5 $\mu \mathrm{m}$ together with the most significant side phase, an unknown $\mathrm{Ba} / \mathrm{P} / \mathrm{O} / \mathrm{N}$ compound in the form of nanometer-sized platelets.
Indexing and Structure Solution. As no single crystals of adequate dimensions were available, it was a challenge to solve the structure from PXRD data obtained from multiphase samples of $\mathrm{Ba}_{19} \mathrm{P}_{36} \mathrm{O}_{6+x} \mathrm{~N}_{66-x} \mathrm{Cl}_{8+x}(x \approx 4.54)$. Starting with data from conventional laboratory diffractometers, indexing was not possible due to low resolution (with Mo K $\alpha$ radiation) or a bad signal-tonoise ratio (with $\mathrm{Cu} \mathrm{K} \alpha$ radiation). An unambiguous determination of the unit cell was additionally impeded by several reflections with low intensity at low angles; it was unclear whether the latter are superstructure reflections or due to unknown side phases. Indexing became possible and fairly unambiguous after evaluating of high-resolution synchrotron PXRD data from different samples. As each sample contains different impurity phases, the reflections of the main phase $\mathrm{Ba}_{19} \mathrm{P}_{36} \mathrm{O}_{6+x} \mathrm{~N}_{66-x} \mathrm{Cl}_{8+x}(x \approx 4.54)$ could be clearly identified. While initially a cP unit cell with $a=1341.62 \mathrm{pm}$ had been considered, a $\mathrm{cF}$ unit cell with a doubled lattice parameter was suggested by reflections that could be superstructure reflections $(h, k, l=2 n+1)$. Although the doubling of $a$ results in an 8 -fold cell volume due to the F-centering, this, however, exhibits a 2 -fold superstructure. To exclude the possibility that these reflections are due to unknown impurities, the 2-fold superstructure was subsequently confirmed by SAED. Figure 3 compares the experimental diffraction pattern of the $[0-15]$ zone axis with respective simulations on the basis of structure models in the primitive ( $a=$ $1342.95 \mathrm{pm})$ and in the F-centered $(a=2685.41 \mathrm{pm})$ cell. The appearances of reflections on odd lines, e.g., reflections with indices $h 15$, require the doubled lattice parameter. A further comparison of a simulated and an experimental electron diffraction pattern is indicated in the Supporting Information (Figure S1).

As some $\mathrm{cF}$ space groups are indistinguishable by means of reflection conditions, STEM-HAADF images along [100] and [110] (Figure 4, left) have been used to derive the correct space group. Comparison of their plane groups ( $p 4 \mathrm{~mm}$ (top) and p $2 \mathrm{~mm}$ (bottom)) with the symmetry of the special projections leaves only two options $(F m \overline{3} c, F d \overline{3} c)$. As $F d \overline{3} c$ is not consistent with the extinction conditions analyzed in the PXRD pattern, $F m \overline{3} c$ is unambiguously the correct space group.

Structure solution succeeded $\mathrm{ab}$ initio by applying the chargeflipping algorithm. ${ }^{23}$ Initially, the $\mathrm{Ba}, \mathrm{P}$, and fully occupied $\mathrm{Cl}$ positions have been located. The correctness of the heavy-atom 


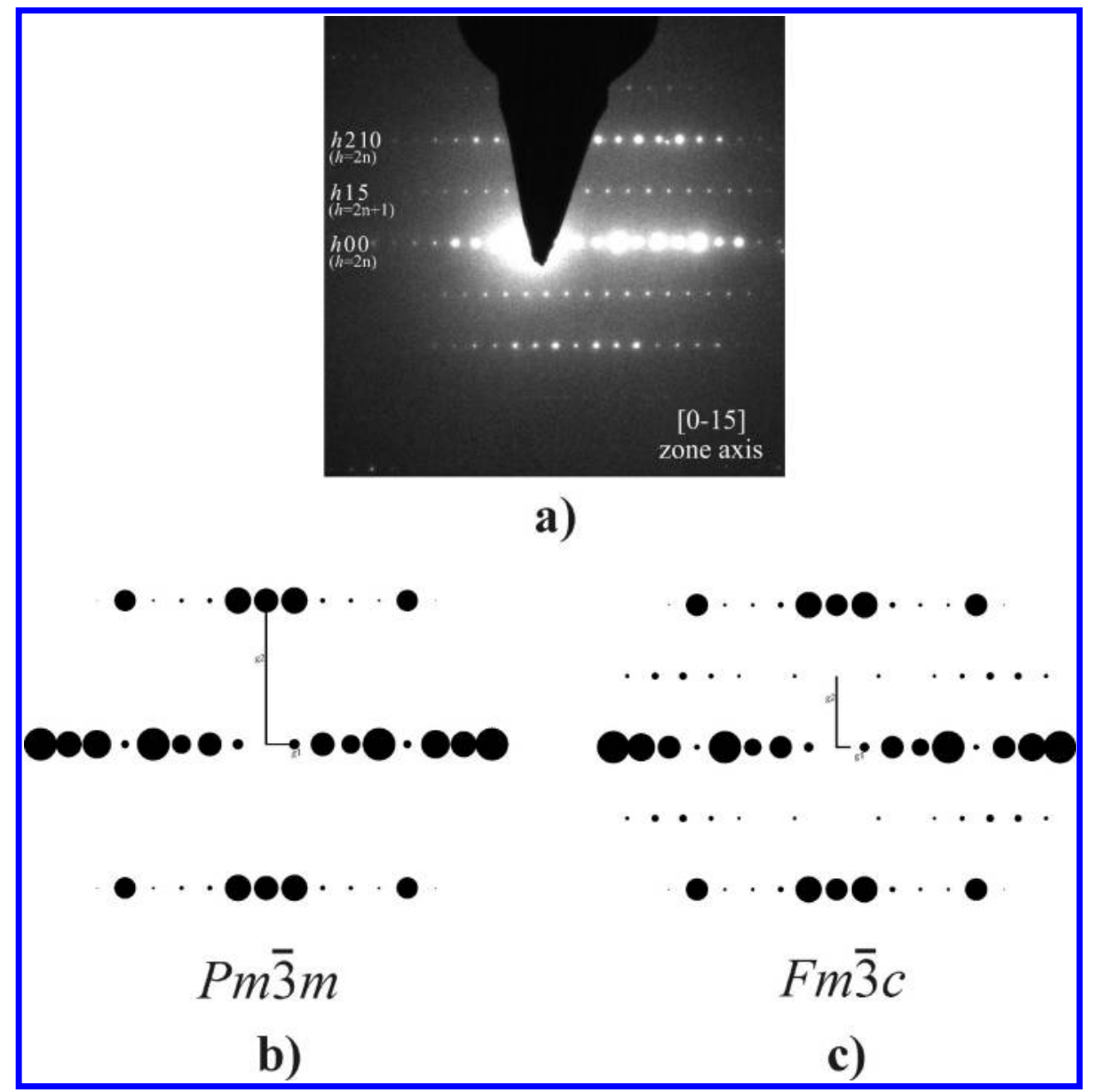

Figure 3. (a) SAED pattern of a cuboidal microcrystal of $\mathrm{Ba}_{19} \mathrm{P}_{36} \mathrm{O}_{6+x} \mathrm{~N}_{66-x} \mathrm{Cl}_{8+x}(x \approx 4.54)$ (top) and corresponding kinematic simulations of electron diffraction patterns in the [0-15] zone axis for structure models refined in space groups $P m \overline{3} m$ (b) and $F m \overline{3} c$ (c).

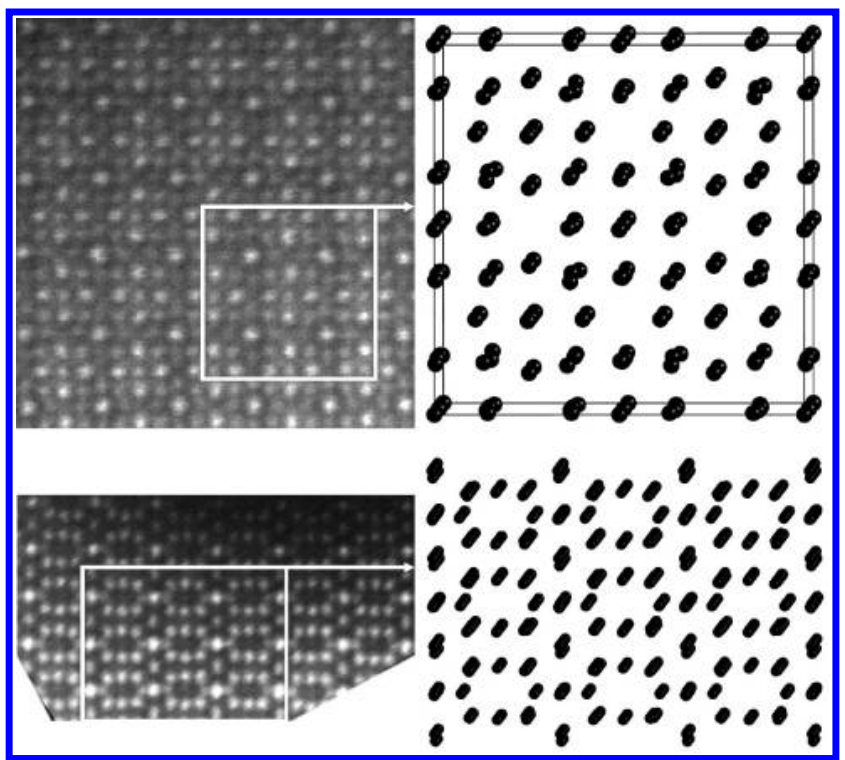

Figure 4. STEM-HAADF images (left) indicating the heavy atom structure (right) of $\mathrm{Ba}_{19} \mathrm{P}_{36} \mathrm{O}_{6+x} \mathrm{~N}_{66-x} \mathrm{Cl}_{8+x}(x \approx 4.54)$. Top: image along [100] with plane group $\mathrm{p} 4 \mathrm{~mm}$. Bottom: image along [110] with plane group $\mathrm{p} 2 \mathrm{~mm}$.

positions was corroborated by the STEM-HAADF images. Incorrect solutions regarding heavy atom positions could be directly identified because of the atomic number sensitivity of the STEM-HAADF in [100] and [110]. Figure 4 depicts the match of the heavy-atom structure with the STEM images. The final crystal structure has been elucidated by evaluation of difference Fourier maps generated after refinements of fragmentary structure models and placing additional bridging atoms at reasonable positions. The final Rietveld refinement of the complete structure model was performed in space group $F m \overline{3} c$. This is reasonable as almost all superstructure reflections are observed, although they are rather weak. Additionally, refinement of the basic structure in space group $P m \overline{3} m$ was done as well. The results are given in the Supporting Information (Tables S1 and S2).

NMR Study. In addition to the X-ray/electron diffraction data, solid-state NMR spectroscopic investigations have been performed. These experiments can add further information about the structure, for example, if hydrogen is present in the title compound. Thereby, additional evidence for the structural model of $\mathrm{Ba}_{19} \mathrm{P}_{36} \mathrm{O}_{6+x} \mathrm{~N}_{66-x} \mathrm{Cl}_{8+x}(x \approx 4.54)$ has been obtained by an independent method.

A quantitative ${ }^{31} \mathrm{P}$ NMR spectrum is shown at the top of the 2D spectrum in Figure 5. Two peaks are observed at -4.6 and $-17.7 \mathrm{ppm}$. These shift values agree well with NMR data of most other nitridophosphates ${ }^{36}$ and oxonitridophosphates (oxonitridosodalite, $-8.7 \mathrm{ppm}^{7} \mathrm{NPO}$ type material, 6.5, -0.1 ppm; $\left.{ }^{9} \mathrm{Sr}_{3} \mathrm{P}_{6} \mathrm{O}_{6} \mathrm{~N}_{8}, 2.6 \mathrm{ppm}\right) .{ }^{37}$ With the resolution power of a ${ }^{31} \mathrm{P}$ double-quantum filtered $2 \mathrm{D}$ spectrum, several independent 


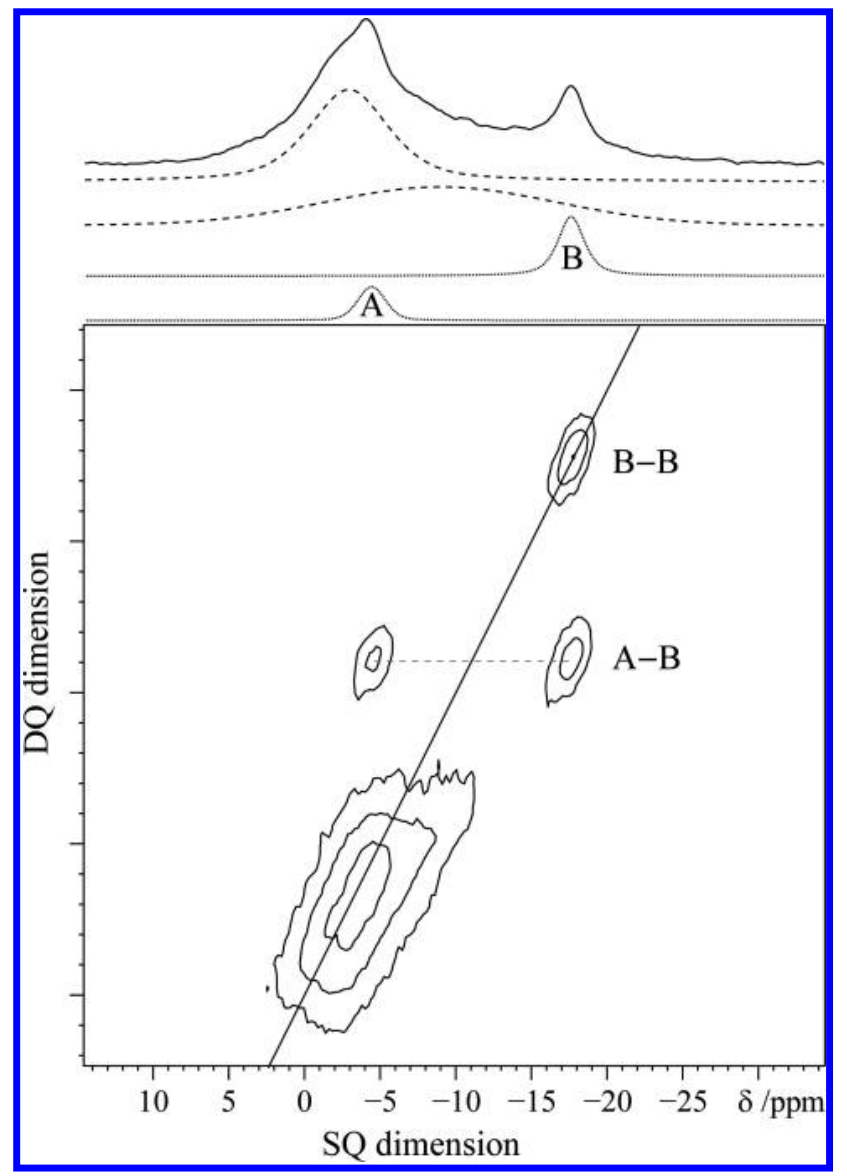

Figure 5. ${ }^{31} \mathrm{P}$-MAS NMR double-quantum (DQ) single-quantum (SQ) correlation spectrum of $\mathrm{Ba}_{19} \mathrm{P}_{36} \mathrm{O}_{6+x} \mathrm{~N}_{66-x} \mathrm{Cl}_{8+x}(x \approx 4.54)$. The quantitative $1 \mathrm{D}$ spectrum (top) was obtained by direct excitation, and below are the individual line shapes of the four Gaussian/Lorentzian profiles which were obtained by constrained line shape deconvolution (dashed lines, amorphous; dotted lines, crystalline). The diagonal is indicating the position of DQ coherences of two isochronous nuclei. The sharp DQ coherences of two crystalline ${ }^{31} \mathrm{P}$ sites are visible next to a broad autocorrelated DQ peak which is assigned to an amorphous impurity.

Table 3. Peak Assignment in the Quantitative Spin-Echo ${ }^{31} \mathrm{P}$ NMR Spectrum of $\mathrm{Ba}_{19} \mathrm{P}_{36} \mathrm{O}_{6+x} \mathrm{~N}_{66-x} \mathrm{Cl}_{8+x}(x \approx 4.54)$

\begin{tabular}{rrrl}
$\delta_{\text {iso }} / \mathrm{ppm}$ & peak area/au & $T_{1} / \mathrm{s}$ & assignment \\
-17.7 & 10.0 & 13 & $\mathrm{P}(1)$, peak B \\
-4.6 & 5.2 & 4 & $\mathrm{P}(2)$, peak A \\
-9.1 & 42.9 & 48 & amorphous \\
-3.1 & 44.1 & 67 & amorphous \\
\hline
\end{tabular}

resonances can be revealed (see Figure 5). The two sharp resonances, labeled $\mathrm{A}$ and $\mathrm{B}$, are assigned to the two $\mathrm{P}$ sites of the title compound, which lead to the double-quantum coherences $\mathrm{B}-\mathrm{B}$ and $\mathrm{A}-\mathrm{B}$. They can clearly be distinguished from a broad contribution which is probably due to an amorphous impurity. It is much broader and has its center of gravity in the range of peak $\mathrm{A}$ of the crystalline title compound. The ${ }^{31} \mathrm{P}$ peaks were assigned according to their peak areas and according to the different frequency of the $\mathrm{P}$ sites in the unit cell (Wyckoff positions $192 j(\mathrm{P} 1)$ and $96 h$ (P2), Table 3). To obtain reliable

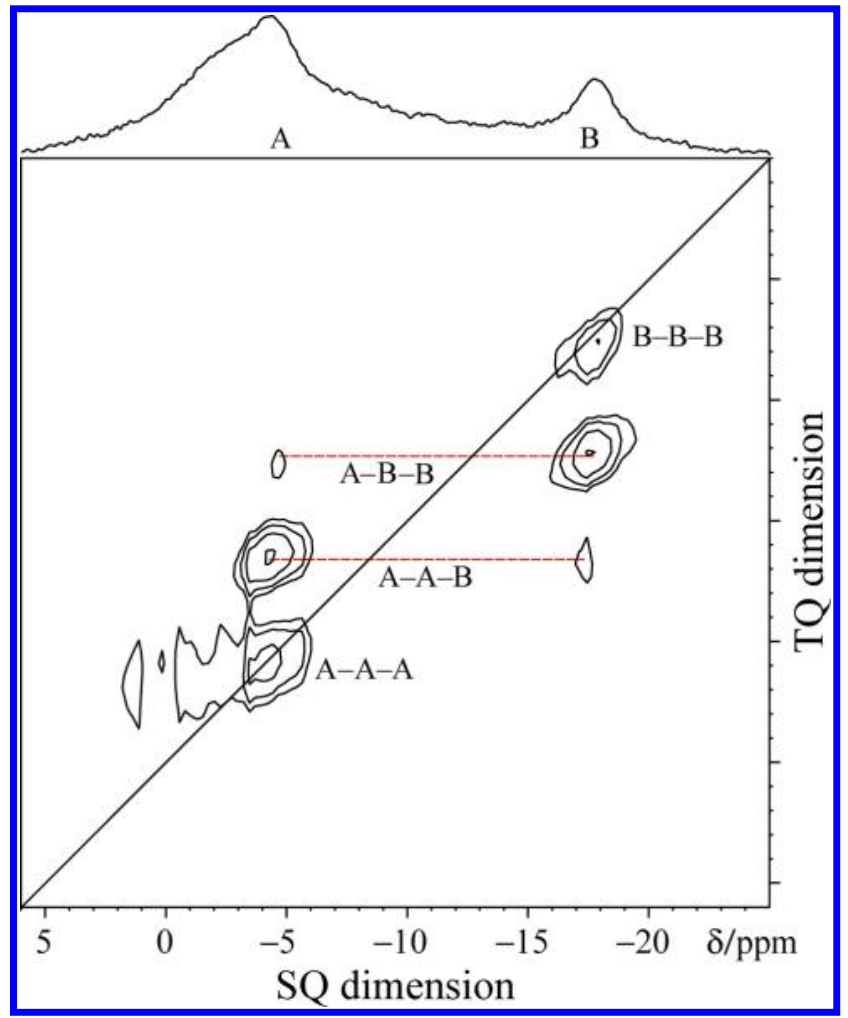

Figure 6. ${ }^{31} \mathrm{P}$-MAS NMR triple-quantum (TQ) single-quantum (SQ) correlation spectrum of $\mathrm{Ba}_{19} \mathrm{P}_{36} \mathrm{O}_{6+x} \mathrm{~N}_{66-x} \mathrm{Cl}_{8+x}(x \approx 4.54)$. The $1 \mathrm{D}$ spectrum (top) was obtained by direct excitation; the diagonal is indicating the position of TQ coherences of three isochronous nuclei; and the peaks labeled with $\mathrm{A}-\mathrm{A}-\mathrm{A}, \mathrm{A}-\mathrm{A}-\mathrm{B}, \mathrm{A}-\mathrm{B}-\mathrm{B}$, and $\mathrm{B}-\mathrm{B}-\mathrm{B}$ belong to the title compound. The amorphous impurity is almost perfectly suppressed.

results, the line shape parameters were first constrained on the sum projection of the $\mathrm{A}-\mathrm{B} \mathrm{DQ}$ resonance in the $2 \mathrm{D}$ spectrum. Subsequently, the quantitative spin-echo spectrum was deconvoluted which resulted in a 5.2:10.0 peak area ratio for peaks A and $\mathrm{B}$, respectively. The deconvolution data in Table 3 also show that-besides P-containing impurities - a high proportion of the sample is amorphous or heavily disordered. In agreement with the SEM image (Figure 2), we conclude that during the reaction first amorphous particles are formed and later crystallization sets in from the particle surface.

To clarify whether the sharp and broad peaks originate from the same phase, for example, in the form of a crystal with regions of heavy and weak $\mathrm{N} / \mathrm{O}$ disorder, a ${ }^{31} \mathrm{P}$ triple-quantum filtered 2D spectrum (Figure 6) was acquired. This cannot be concluded from the ${ }^{31} \mathrm{P}$ double-quantum filtered $2 \mathrm{D}$ spectrum because of the spectral overlap of peak A with the broad features. ${ }^{31} \mathrm{P}$ triplequantum coherences, which are expected for the crystalline title compound, are only observed between peaks A and B, while the broad contributions centered around -3 and $-9 \mathrm{ppm}$ are reduced in intensity. It is noteworthy that the triple-quantum coherences involving phosphorus atoms $\mathrm{P}(1)$ and $\mathrm{P}(2)$ are not related to the broad features. Hence, the description of the sample as a heterogeneous mixture of the title compound and an amorphous impurity is consistent with the triple-quantum filtered 2D correlation spectrum (Figure 6). Furthermore, the signal pattern of the spectrum with its linking schemes $A-A-A$, 


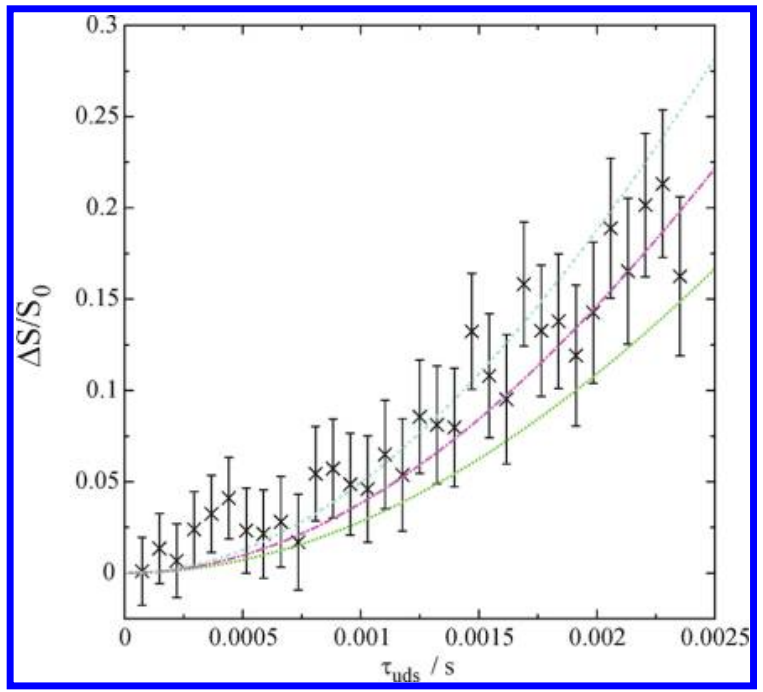

Figure 7. ${ }^{31} \mathrm{P}\left\{{ }^{1} \mathrm{H}\right\}$ REDOR curve of $\mathrm{Ba}_{19} \mathrm{P}_{36} \mathrm{O}_{6+x} \mathrm{~N}_{66-x} \mathrm{Cl}_{8+x}(x \approx$ 4.54) (in black). The plotted lines in green, cyan, and magenta indicate simulated REDOR curves calculated with dipolar coupling constants of $-60,-70$, and $-80 \mathrm{~Hz}$, respectively. The REDOR experiment proves a small, nonstoichiometric $(\mathrm{H}$ atoms/unit cell $<1)$ contamination with hydrogen atoms, which is often observed in zeolites. ${ }^{38}$

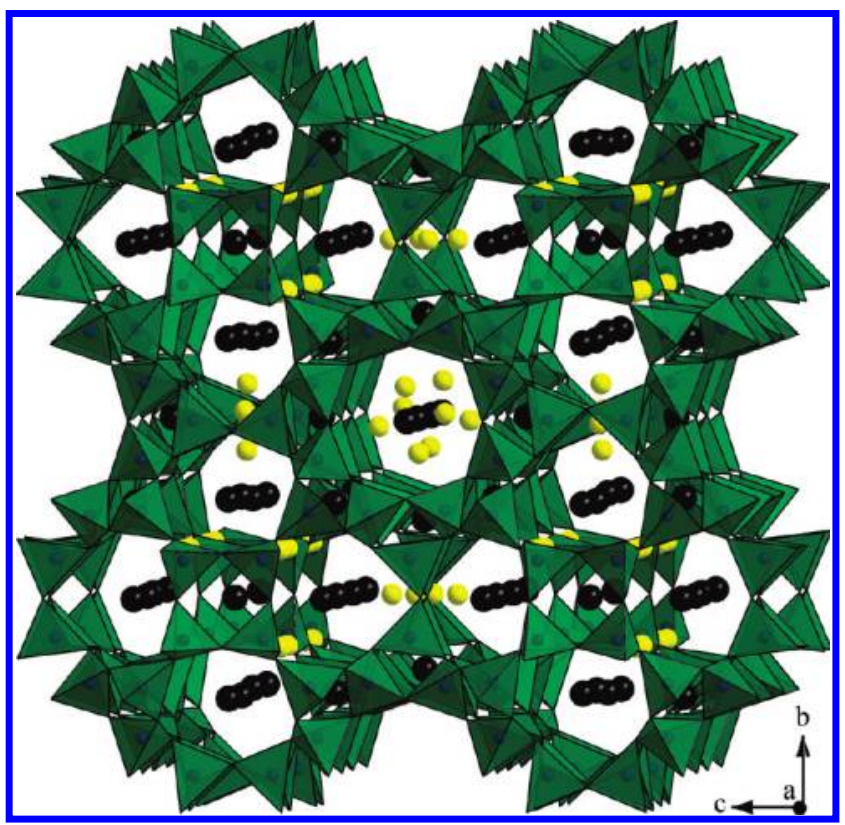

Figure 8. Crystal structure of $\mathrm{Ba}_{19} \mathrm{P}_{36} \mathrm{O}_{6+x} \mathrm{~N}_{66-x} \mathrm{Cl}_{8+x}(x \approx 4.54)$. View along $[100]\left(\mathrm{Ba}^{2+}\right.$ black, $\mathrm{Cl}^{-}$yellow, $\mathrm{P}(\mathrm{O}, \mathrm{N})_{4}$ tetrahedra green $)$.

$\mathrm{A}-\mathrm{A}-\mathrm{B}, \mathrm{A}-\mathrm{B}-\mathrm{B}$, and $\mathrm{B}-\mathrm{B}-\mathrm{B}$ corroborates the refined structure model.

In the NPO $\mathrm{Li}_{x} \mathrm{H}_{12-x-y+z}\left[\mathrm{P}_{12} \mathrm{O}_{y} \mathrm{~N}_{24-y}\right] \mathrm{X}_{z}(\mathrm{X}=\mathrm{Cl}, \mathrm{Br})$ or the oxonitridosodalithes $\mathrm{M}_{8-m} \mathrm{H}_{m}\left[\mathrm{P}_{12} \mathrm{~N}_{18} \mathrm{O}_{6}\right] \mathrm{Cl}_{2}(\mathrm{M}=\mathrm{Cu}, \mathrm{Li})$, hydrogen atoms are bound to the bridging nitrogen atoms forming imide groups. The occurrence of hydrogen in $\mathrm{Ba}_{19} \mathrm{P}_{36} \mathrm{O}_{6+x^{-}}$ $\mathrm{N}_{66-x} \mathrm{Cl}_{8+x}(x \approx 4.54)$ is difficult to prove or disprove with diffraction techniques on an inhomogeneous mixture and because of the oxygen and nitrogen site disorder. NMR however is rather sensitive to small amounts of hydrogen in the structure. The ${ }^{31} \mathrm{P}\left\{{ }^{1} \mathrm{H}\right\}$ C-REDOR experiment can be used to investigate

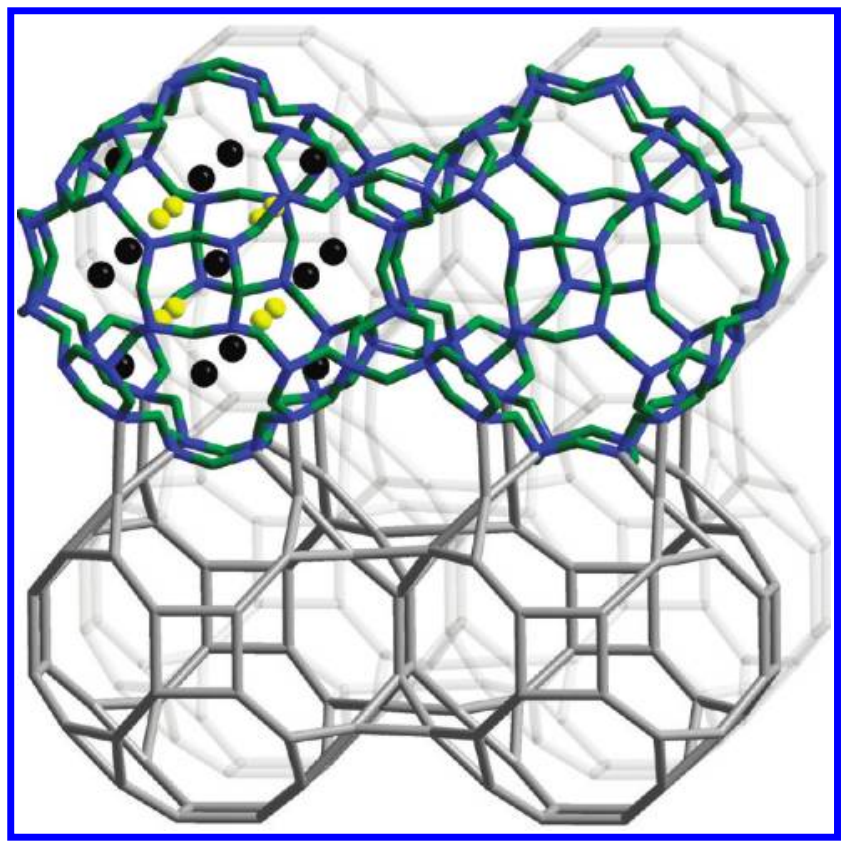

Figure 9. Interconnected $3^{8} 4^{6} 8^{12}$ cages in $\mathrm{Ba}_{19} \mathrm{P}_{36} \mathrm{O}_{6+x} \mathrm{~N}_{66-x} \mathrm{Cl}_{8+x}$ $(x \approx 4.54)$. Top: drawing with $\mathrm{P}-\mathrm{N}$ bonding and cage content (left). Bottom: representation with only $\mathrm{P}-\mathrm{P}$ linking.

the stoichiometric occurrence of hydrogen in the structure. The experimental REDOR curve of the deconvoluted peak B is shown in Figure 7 together with three calculated curves for different dipolar coupling constants of $-60,-70$, and $-80 \mathrm{~Hz}$ which refer to internuclear distances $\mathrm{P}-\mathrm{H}$ of 933,886 , and $847 \mathrm{pm}$, respectively. There is no point in the unit cell which has such a large distance from atom $\mathrm{P}(1)$. Hence, the REDOR curves prove that small amounts of hydrogen are incorporated into the structure; however, the observed slow dephasing effects are indicative of substoichiometric hydrogen content $(\mathrm{H}$ atoms/unit cell $<1$ ) only. Similar observations have been made previously for many zeolites. ${ }^{38}$

Structure Description and Discussion. The crystal structure of $\mathrm{Ba}_{19} \mathrm{P}_{36} \mathrm{O}_{6+x} \mathrm{~N}_{66-x} \mathrm{Cl}_{8+x}(x \approx 4.54)$ (Figure 8 ) consists of $\mathrm{Ba}^{2+}$ ions, $\mathrm{Cl}^{-}$ions, and a framework of all-side vertex-sharing $\mathrm{P}(\mathrm{O} / \mathrm{N})_{4}$ tetrahedra representing an unprecedented topology that has been predicted by Foster and Treacy as a hypothetical zeolite structure on the $\mathrm{SiO}_{2}$ basis. ${ }^{39}$

According to the IUPAC ${ }^{40}$ formula $\left|\mathrm{Ba}_{19}^{2+} \mathrm{Cl}_{8+x}^{-}\right|\left[\mathrm{P}_{36}^{+\mathrm{V}[4]} \mathrm{O}_{6+x}^{-\mathrm{II}[2]}\right.$ $\left.\mathrm{N}_{66-x}^{-\mathrm{III}[2]}\right]_{h}\left\{3\left[3^{8} 4^{6} 8^{12}\right]\right\}_{p}\left\{3\left[3^{8} 8^{6}\right]\langle 100\rangle(8\right.$-ring $\left.)\right\}(F m \overline{3} \mathrm{c})$, the tetrahedra build up 3-, 4-, and 8-rings forming $3^{8} 4^{6} 8^{12}$ cages that exhibit a CBU (Figure 9) that is not included in the current pool of CBU types so far. ${ }^{41}$ The idealized solid body corresponds to the RCSR symbol $r d o-a{ }^{42}$ It can be derived from the Catalan polyhedron of a rhombic dodecahedron by grinding off all vertices. Interconnecting the novel $\mathrm{CBUs}$ via their 4-rings (forming additional 3-rings) yields 8-ring channels along $\langle 100\rangle$ with a free diameter of $292 \mathrm{pm}$ (calculation considering $r(\mathrm{~N})=$ $147 \mathrm{pm}$ ). The coordination sequences and the vertex symbols for the framework (RCSR symbol fuv $)^{42}$ are given in the Supporting Information (Table S4).

The observed $\left[\mathrm{P}_{n}(\mathrm{~N} / \mathrm{O})_{n}\right]$ ring sizes and their relative frequency, i.e., the cycle class sequence according to Klee, ${ }^{43}$ are listed in Table 4 (calculated with the program TOPOLAN) ${ }^{44}$ In contrast to the sodalite framework (SOD) or the framework of 
Table 4. Cycle Class Sequence from the Framework in $\mathrm{Ba}_{19} \mathrm{P}_{36} \mathrm{O}_{6+x} \mathrm{~N}_{66-x} \mathrm{Cl}_{8+x}(x \approx 4.54)$ in Comparison with Frameworks SOD and LTA

\begin{tabular}{lrrrrrrrr}
\multicolumn{1}{c}{$\mathrm{P}_{n}(\mathrm{O}, \mathrm{N})_{n}$-rings } & 3 & 4 & 5 & 6 & 7 & 8 & 9 & 10 \\
$\mathrm{Ba}_{19} \mathrm{P}_{36} \mathrm{O}_{6+x} \mathrm{~N}_{66-x} \mathrm{Cl}_{8+x}$ & 19 & 4 & 4 & 8 & 12 & 31 & 129 & 388 \\
SOD & 0 & 3 & 0 & 4 & 0 & 24 & 0 & 576 \\
LTA & 0 & 18 & 0 & 56 & 0 & 69 & 0 & 360 \\
\hline
\end{tabular}

Table 5. Selected Interatomic Distances $/ \mathrm{pm}$ and Angles $/{ }^{\circ}$ in $\mathrm{Ba}_{19} \mathrm{P}_{36} \mathrm{O}_{6+x} \mathrm{~N}_{66-x} \mathrm{Cl}_{8+x}(x \approx 4.54)$ (esd's in Parentheses)

$\begin{array}{lll}\begin{array}{l}\mathrm{Ba}(1)-\mathrm{Cl} \\ (\text { partially occupied })\end{array} & 311.0(12) & 4 \text { times } \\ \mathrm{Ba}(2)-\mathrm{Cl} & 317.6(4), 334.2(16) & 3 \text { times } \\ \mathrm{Ba}(3)-\mathrm{Cl} & 320.3(4) & 8 \text { times } \\ \mathrm{Ba}(1)-(\mathrm{O}, \mathrm{N}) & 308.1(5), 309.4(4) & 8 \text { times } \\ \mathrm{Ba}(2)-(\mathrm{O}, \mathrm{N}) & 288.6(4)-321.4(4) & 7 \text { times } \\ \mathrm{P}-(\mathrm{O}, \mathrm{N}) & 159.1(6)-165.5(5) & 8 \text { times } \\ \mathrm{P}-(\mathrm{O}, \mathrm{N})-\mathrm{P} & 121.5(3), 125.0(2), & \\ & 125.2(3), 141.2(1) & \\ (\mathrm{O}, \mathrm{N})-\mathrm{P}-(\mathrm{O}, \mathrm{N}) & 99.0(2)-119.2(2) & 12 \text { times }\end{array}$

LTA that comprise cubic $\beta-\left(4^{6} 6^{8}\right)$ and $\alpha-\left(4^{12} 6^{8} 8^{6}\right)$ cages, all ring sizes do exist in $\mathrm{Ba}_{19} \mathrm{P}_{36} \mathrm{O}_{6+x} \mathrm{~N}_{66-x} \mathrm{Cl}_{8+x}(x \approx 4.54)$. Notably, many 3-rings are present, although they rarely occur in zeolite topologies (in only 15 of 194 framework types registered in the IZA database). However, when low framework densities should be achieved, small rings are relevant according to the theory of Brunner and Meier. ${ }^{45}$ With a high 3-ring frequency of 19 and a framework density of $14.87 \mathrm{~T} / 1000 \AA^{3}$, which is rather low considering the typical range of zeolites $\left(12.5-20.2 \mathrm{~T} / 1000 \AA^{3}\right)$, this theory is supported by the findings in the case of $\mathrm{Ba}_{19} \mathrm{P}_{36^{-}}$ $\mathrm{O}_{6+x} \mathrm{~N}_{66-x} \mathrm{Cl}_{8+x}(x \approx 4.54)$.

The $3^{8} 4^{6} 8^{12}$ cages in $\mathrm{Ba}_{19} \mathrm{P}_{36} \mathrm{O}_{6+x} \mathrm{~N}_{66-x} \mathrm{Cl}_{8+x}(x \approx 4.54)$ are slightly distorted from the symmetry of the regular polyhedron $(m \overline{3} m)$. This distortion causes two different cages in the unit cell which are crystallographically independent and thus the necessity of the 2-fold superstructure described in $F m \overline{3} c$. Neglecting the superstructure reflections and accepting just slightly higher $R$ values, the structure can be described in $P m \overline{3} m$ (crystallographic data of this basic structure are given in the Supporting Information, Tables S1 and S2) including only one less distorted cage. The number of independent atom sites is identical in both models; however, $\mathrm{P}$ and $\mathrm{O} / \mathrm{N}$ atoms occupy more special positions in the approximate basic structure, while they occupy more general ones in the correct space group. To quantify the distortion of the cages in the $F m \overline{3} c$ model and to clarify the difference to the model in $P m \overline{3} m$, a conformation analysis of the 3- and 4-rings, i.e., the 6-membered $\mathrm{P}_{3}(\mathrm{O}, \mathrm{N})_{3}$ and 8-membered $\mathrm{P}_{4}(\mathrm{O}, \mathrm{N})_{4}$ rings, ${ }^{46}$ has been performed calculating the torsion angle sequence (TAS) as well as the displacement asymmetry (DAP, see Supporting Information, Figure S2) ${ }^{47}$ and the puckering parameters ${ }^{48}$ with the program PARST97. ${ }^{49}$ The 6-membered rings exhibit a chair conformation in both models, which, combined with a tiny interference of a sofa conformation, is more pronounced in $F m \overline{3} c$. This can be clearly seen considering the respective values (Supporting Information, section 3). A larger difference is found within the 8 -membered $\mathrm{P}_{4}(\mathrm{O}, \mathrm{N})_{4}$ rings. While they are planar in $P m \overline{3} m$ (all torsion angles are zero), a

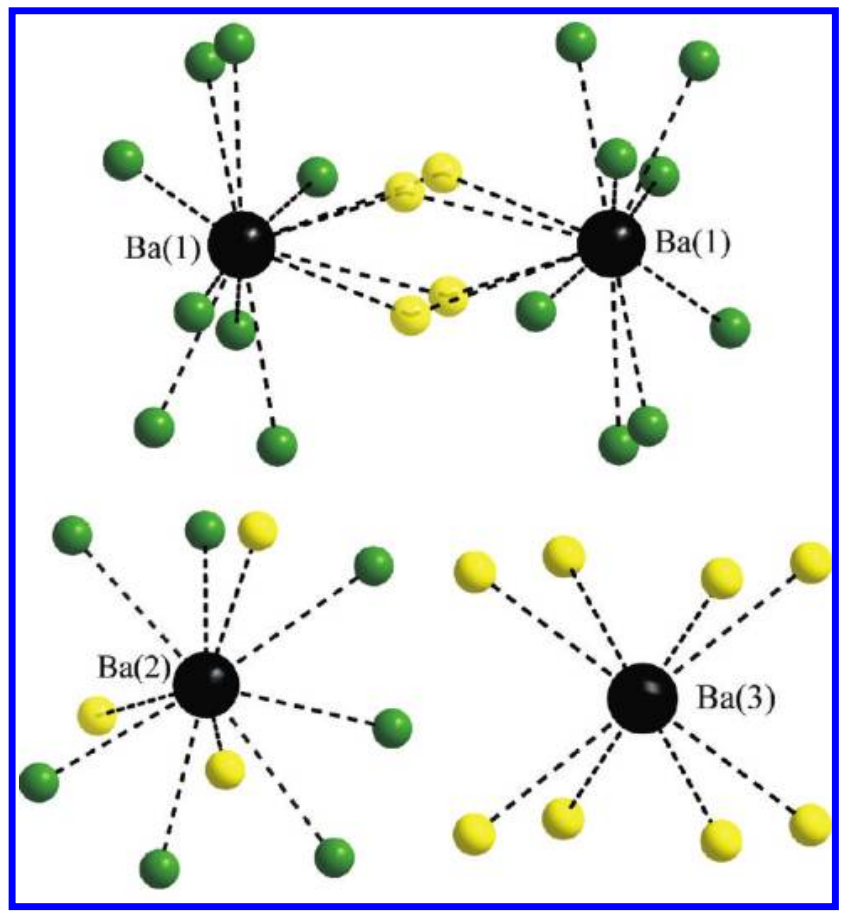

Figure 10. Coordination of the $\mathrm{Ba}$ sites in $\mathrm{Ba}_{19} \mathrm{P}_{36} \mathrm{O}_{6+x} \mathrm{~N}_{66-x} \mathrm{Cl}_{8+x}$ $(x \approx 4.54)\left(\mathrm{Ba}^{2+}\right.$ black, $\mathrm{Cl}^{-}$yellow (partially occupied ones are hold transparent), (O,N) green).

saddle conformation with an intermixture of a twist chair for the conformation in $F m \overline{3} c$ is suggested by the values given in the Supporting Information (section 3).

In the Rietveld refinement, constraints were included to fit distances and angles within the tetrahedra into the usual range observed in phosphorus nitride network structures. ${ }^{9,36,46}$ With a certain permitted deviation the distances $\mathrm{P}-(\mathrm{O}, \mathrm{N})$ vary between 159.1 and $165.5 \mathrm{pm}$ and the angles $(\mathrm{O}, \mathrm{N})-\mathrm{P}-(\mathrm{O}, \mathrm{N})$ between 99.0 and $119.2^{\circ}$ (Table 5). The angles $\mathrm{P}-(\mathrm{O}, \mathrm{N})-\mathrm{P}$ of the final model range between 121.5 and $141.2^{\circ}$ (Table 5), comparable to angles in compounds like $\mathrm{P}_{4} \mathrm{~N}_{4}(\mathrm{NH})_{4} \cdot \mathrm{NH}_{3}{ }^{12}$ or $\mathrm{SrP}_{2} \mathrm{~N}_{4} \cdot{ }^{50}$ Also within the corresponding hypothetical ideal $\mathrm{SiO}_{2}$ framework generated by a distance-least-squares refinement with DLS76, ${ }^{51}$ rather small angles $\mathrm{Si}-\mathrm{O}-\mathrm{Si}$ down to $159.684(2)^{\circ}$ are existent. This might be the reason why this framework has not been realized in an oxidic system as of yet.

We assume a statistic $\mathrm{O}, \mathrm{N}$-distribution in the $\mathrm{P} / \mathrm{O} / \mathrm{N}$ network of $\mathrm{Ba}_{19} \mathrm{P}_{36} \mathrm{O}_{6+x} \mathrm{~N}_{66-x} \mathrm{Cl}_{8+x}(x \approx 4.54)$. As there are no predestined positions for $\mathrm{O}$ or $\mathrm{N}$ and such statistic $\mathrm{O}, \mathrm{N}$-distributions were already observed in other $\mathrm{P} / \mathrm{O} / \mathrm{N} \mathrm{TX}_{2}$ networks, ${ }^{9,6,7,52}$ this assumption is reasonable. Possible $\mathrm{O}, \mathrm{N}$ ordering in $\mathrm{Ba}_{19} \mathrm{P}_{36^{-}}$ $\mathrm{O}_{6+x} \mathrm{~N}_{66-x} \mathrm{Cl}_{8+x}(x \approx 4.54)$ could only be analyzed by neutron diffraction. From the refined sum formula $\mathrm{Ba}_{19} \mathrm{P}_{36} \mathrm{O}_{10.54^{-}}$ $\mathrm{N}_{61.46} \mathrm{Cl}_{12.54}$ that is confirmed by semiquantitative EDX analysis within the accuracy of the method (calcd: $\mathrm{Ba}: \mathrm{Cl}=1.5, \mathrm{Ba}: \mathrm{P}=0.5$, $\mathrm{P}:(\mathrm{O}, \mathrm{N})=0.5, \mathrm{P}: \mathrm{Cl}=2.9, \mathrm{~N}: \mathrm{O}=5.8$; exptl: $\mathrm{Ba}: \mathrm{Cl}=1.3, \mathrm{Ba}: \mathrm{P}=$ 0.6, P: $(\mathrm{O}, \mathrm{N})=0.4, \mathrm{P}: \mathrm{Cl}=2.4, \mathrm{~N}: \mathrm{O}=4.4)$, on average $56 \% \mathrm{PN}_{4}$ and $44 \% \mathrm{PON}_{3}$ tetrahedra are present.

The framework in $\mathrm{Ba}_{19} \mathrm{P}_{36} \mathrm{O}_{6+x} \mathrm{~N}_{66-x} \mathrm{Cl}_{8+x}(x \approx 4.54)$ provides a "free" volume of $4484.3 \AA^{3}$ (23.2\% of the cell volume). Within this volume, which comprises the 8-ring channels and the interior of the cages, the extra-framework ions $\mathrm{Ba}^{2+}$ and $\mathrm{Cl}^{-}$are located. One $\mathrm{Ba}^{2+}$ site lies directly in the center of the cages 
coordinated by a cube of eight $\mathrm{Cl}^{-}$ions at a distance of $320.3 \mathrm{pm}$ (Figure 10, $\mathrm{Ba}(3)$ ), corresponding to the content of one unit cell of the $\mathrm{CsCl}$ structure type. Around the $\mathrm{BaCl}_{8}{ }^{6-}$ units, 12 more $\mathrm{Ba}^{2+}$ ions are located within each cage. These ions are coordinated 10-fold by seven $(\mathrm{O}, \mathrm{N})$ atoms $(288.6-321.4 \mathrm{pm})$ of the cage and three $\mathrm{Cl}^{-}$ions (317.6 and $334.2 \mathrm{pm}$; Figure 10, $\mathrm{Ba}(2)$ ). The $\mathrm{Ba}^{2+}$ ions along the 8-ring channels are arranged in pairs with an intrapair distance of $566.5 \mathrm{pm}$ and $\mathrm{Cl}^{-}$ions in between (Figure 10, $\mathrm{Ba}(1)$ ). The four $\mathrm{Cl}^{-}$positions are staggered from pair to pair (cf. Figure 8) and have, due to their partial occupancy (about $40 \%$ ), with $311.0 \mathrm{pm}$ the shortest $\mathrm{Ba}-\mathrm{Cl}$ distance in $\mathrm{Ba}_{19} \mathrm{P}_{36} \mathrm{O}_{6+x} \mathrm{~N}_{66-x} \mathrm{Cl}_{8+x}(x \approx 4.54)$. Furthermore, the $\mathrm{Ba}^{2+}$ ions involved in the pairs which have an interpair distance of 1342.7 pm are surrounded each by eight $(\mathrm{O}, \mathrm{N})$ atoms with distances between 308.1 and $309.4 \mathrm{pm}$. All $\mathrm{Ba}-\mathrm{Cl}$ and $\mathrm{Ba}-(\mathrm{O}, \mathrm{N})$ contacts, summarized in Table 5, range in the sum of the respective ionic radii. ${ }^{53,54}$ Although the cages and channels are quite crowded with $\mathrm{Ba}^{2+}$ and $\mathrm{Cl}^{-}$, there is still free space (about $38 \AA^{3}$ ) between the $\mathrm{Ba}^{2+}$ ions that are situated in the periphery of the cage interior in a distance of around $200 \mathrm{pm}$ to the bridging atoms $\mathrm{O}, \mathrm{N}$. Replacing $\mathrm{Cl}^{-}$and $\mathrm{Br}^{-}$ions can also be partially introduced by adding $\mathrm{NH}_{4} \mathrm{Br}$ to the starting material mixture. A replacement of $\mathrm{Cl}^{-}$by $\mathrm{Br}^{-}$could be proved obtaining cubic microcrystals (Figure S3, Supporting Information) that contain the elements $\mathrm{Ba}, \mathrm{P}, \mathrm{O}, \mathrm{N}, \mathrm{Cl}$, and $\mathrm{Br}$ (EDX analysis) and powder diffraction data where all reflections move to lower $2 \theta$-values compared to the pure $\mathrm{Cl}^{-}$containing compound ( $a=$ $2691.06(3) \mathrm{pm}$ ). No evidence was observed for incorporation of $\mathrm{I}^{-}$or cations other than $\mathrm{Ba}^{2+}$.

\section{CONCLUSION}

With the novel oxonitridophosphate $\mathrm{Ba}_{19} \mathrm{P}_{36} \mathrm{O}_{6+x} \mathrm{~N}_{66-x} \mathrm{Cl}_{8+x}$ $(x \approx 4.54)$, an unprecedented zeolite-like framework including a new CBU unit has been elucidated. Its discovery and its structure elucidation were highly challenging, as from a complex synthesis system only microcrystalline powder samples with side phases were available. However, applying a combination of high-resolution synchrotron powder diffraction and electron microscopic methods (SAED and STEM), ambiguous data could be clarified, and cubic ( $F m \overline{3} c$ (no. 226), $a=2685.41(3) \mathrm{pm}$ ) $\mathrm{Ba}_{19} \mathrm{P}_{36^{-}}$ $\mathrm{O}_{6+x} \mathrm{~N}_{66-x} \mathrm{Cl}_{8+x}(x \approx 4.54)$ could be established as a compound exhibiting a novel all-side vertex-sharing $\mathrm{P}(\mathrm{O}, \mathrm{N})_{4}$ tetrahedra topology that has been predicted but not observed as of yet. Confirmed and complemented with solid-state NMR spectroscopy, the structure model comprises $\mathrm{Ba}^{2+}$ and $\mathrm{Cl}^{-}$ions which are incorporated in interlinked $3^{8} 4^{6} 8^{12}$ cages and in 8-ring channels with a free diameter of $292 \mathrm{pm}$. If this extra-framework material could be (partially) removed or exchanged by smaller ions, which will be the subject of future investigations, the title compound may be a representative for a small-pore zeolite that can usually be used in pressure swing adsorption (PSA) separation processes. ${ }^{55-57}$ This or other applications seem to be desirable as $\mathrm{Ba}_{19} \mathrm{P}_{36} \mathrm{O}_{6+x} \mathrm{~N}_{66-x} \mathrm{Cl}_{8+x}(x \approx 4.54)$ has a surprising thermal stability up to at least $1100{ }^{\circ} \mathrm{C}$, a temperature where many common zeolites are already decomposed. With this stability, nitride materials would be interesting for catalytic processes that act at high temperatures.

Further improvement and development of the complex synthesis system must be another future goal. After the (oxo-)nitridosodalites and the NPO type materials, $\mathrm{Ba}_{19} \mathrm{P}_{36} \mathrm{O}_{6+x} \mathrm{~N}_{66-x} \mathrm{Cl}_{8+x}$ $(x \approx 4.54)$ is another important example for the use of the multicomponent reactant system with phosphorus triamides, metal halides, and ammonium halides. A comprehensive investigation of the role of the $\mathrm{NH}_{3}$ partial pressure as well as the templating effect of $\mathrm{Ba}^{2+}$ and $\mathrm{Cl}^{-}$would allow one to purposefully optimize the synthesis. Other soft and large ions like $\mathrm{Pb}^{2+}$ or $\mathrm{Sn}^{2+}$ might as well be useful to establish a systematic route for the synthesis of nitridic zeolites and permit novel framework types with low framework densities and thus exploit the full potential of the nitride approach within zeolite chemistry.

\section{ASSOCIATED CONTENT}

S Supporting Information. Simulated electron diffraction pattern compared with the experimental pattern of direction [100], crystallographic data in space group $P m \overline{3} m$, symmetry of 6-membered $\mathrm{P}_{3}(\mathrm{O}, \mathrm{N})_{3}$ and 8-membered $\mathrm{P}_{4}(\mathrm{O}, \mathrm{N})_{4}$ rings, topology analysis (coordination sequences and vertex symbols), and an SEM image of the isostructural phase containing $\mathrm{Br}^{-}$. This material is available free of charge via the Internet at http://pubs.acs.org.

\section{AUTHOR INFORMATION}

\section{Corresponding Author}

wolfgang.schnick@uni-muenchen.de

\section{ACKNOWLEDGMENT}

We gratefully acknowledge financial support that was granted by the Deutsche Forschungsgemeinschaft (DFG) and Fonds der Chemischen Industrie (FCI) (scholarship for S. J. Sedlmaier, Emmy Noether funding for J. Schmedt auf der Günne and J. Weber). Additionally we thank ESRF, Grenoble, France for supplying beamtime and Dr. A. Fitch for his assistance at ID31. Our special thanks go to Dr. C. Bärlocher for the DLS76 calculations and valuable discussions. We also thank C. Minke for numerous SEM images and EDX measurements.

\section{REFERENCES}

(1) Cheetham, A. K.; Férey, G.; Loiseau, T. Angew. Chem. 1999, 111, 3466-3492. Angew. Chem. Int. Ed. 1999, 38, 3268-3292.

(2) Natarajan, S.; Mandal, S. Angew. Chem. 2008, 120, 4876-4907. Angew. Chem. Int. Ed. 2008, 47, 4798-4828.

(3) Wilson, S. T.; Lok, B. M.; Messina, C. A.; Cannan, T. R.; Flanigen, E. M. I. Am. Chem. Soc. 1982, 104, 1146-1147.

(4) (a) Guth, J. L.; Kessler, H.; Wey, R. Stud. Surf. Sci. Catal. 1986, 28, 121-128. Estermann, M.; McCusker, L. B.; Baerlocher, C.; Merrouche, M.; Kessler, H. Nature 1991, 352, 320-323.

(5) Bowes, C. L.; Ozin, G. A. Adv. Mater. 1996, 8, 13-28.

(6) (a) Schnick, W.; Lücke, J. Angew. Chem. 1992, 104, 208-209. Angew. Chem. Int. Ed. Engl. 1992, 31, 213-215. (b) Schnick, W.; Lücke, J. Z. Anorg. Allo. Chem. 1994, 620, 2014-2019. (c) Schnick, W.; Stock, N.; Lücke, J.; Volkmann, M.; Jansen, M. Z. Anorg. Allg. Chem. 1995, 621, 987-992. (d) Wester, F.; Schnick, W. Z. Anorg. Allg. Chem. 1996, 622, 1281-1286.

(7) Stock, N.; Irran, E.; Schnick, W. Chem._Eur. J. 1998, 4, 1822-1828.

(8) Huppertz, H.; Schnick, W. Angew. Chem. 1997, 109, 2765-2767. Huppertz, H.; Schnick, W. Angew. Chem., Int. Ed. Engl. 1997, $36,2651-2652$.

(9) (a) Correll, S.; Oeckler, O.; Stock, N.; Schnick, W. Angew. Chem. 2003, 115, 3674-3677. Angew. Chem. Int. Ed. 2003, 42, 3549-3552. (b) Correll, S.; Stock, N.; Oeckler, O.; Senker, J.; Nilges, T.; Schnick, W. Z. Anorg. Allo. Chem. 2004, 630, 2205-2217. 
(10) Barnes, A. J. D.; Prior, T. J.; Francesconi, M. G. Chem. Commun. 2007, 4638-4640.

(11) Pagano, S.; Oeckler, O.; Schröder, T.; Schnick, W. Eur. J. Inorg. Chem. 2009, 2678-2683.

(12) Karau, F.; Schnick, W. Angew. Chem. 2006, 118, 4617-4620. Anoew. Chem. Int. Ed. 2006, 45, 4505-4508.

(13) Pouchard, M. Nature 2006, 442, 878-879.

(14) Klement, R; Koch, O. Chem. Ber. 1954, 87, 333-340.

(15) Schnick, W. Z. Naturforsch., B: J. Chem. Sci. 1989, 44, 942-945.

(16) Correll, S. Ph.D. Thesis, Univ. Munich (LMU) 2006.

(17) Horstmann, S.; Schnick, W. Z. Naturforsch., B: J. Chem. Sci. 1996, 51, 127-132.

(18) (a) Sowerby, D. B.; Audrieth, L. F. Chem. Ber. 1961, 94, 2670-2675. (b) Golinski, F.; Jacobs, H. Z. Anorg. Allg. Chem. 1994, 620, 965-968.

(19) Stock, N.; Schnick, W. Z. Naturforsch., B: J. Chem. Sci. 1996, 51, 1079-1083.

(20) Hodeau, J.-L.; Bordet, P.; Anne, M.; Prat, A.; Fitch, A. N.; Dooryhee, E.; Vaughan, G.; Freund, A. K. Proc. SPIE 1998, 3448, 353-361.

(21) Coelho, A. A. TOPAS-Academic, Version 4.1; Coelho Software: Brisbane, 2007.

(22) Coelho, A. A. I. Appl. Crustallogr. 2003, 36, 86-95.

(23) Oszlányi, G.; Süto, A. Acta Crystallogr., Sect. A: Found. Crystallogr. 2004, 60, 134-141.

(24) Bergmann, J.; Kleeberg, R.; Haase, A.; Breidenstein, B. Mater. Sci. Forum 2000, 347-349, 303-308.

(25) Sabine, T. M.; Hunter, B. A.; Sabine, W. R.; Ball, C. J. J. Appl. Crystallogr. 1998, 31, 47-51.

(26) Hill, R. J.; Madsen, I. C. J. Appl. Crystallogr. 1984, 17, 297-306.

(27) Hill, R. J.; Flack, H. D. J. Appl. Crystallogr. 1987, 20, 356-361.

(28) Jouneau, P.-H.; Stadelmann, P. Electron Microscopy Image Simulation (EMS On Line); Centre Interdépartemental de Microscopie Electronique, EPFL: Lausanne, 1998: http://cecm.insa-lyon.fr/CIOLS/ crystal1.pl.

(29) Harris, R. K.; Becker, E. D.; Cabral de Menezes, S. M.; Goodfellow, R.; Granger, P. Solid State NMR 2002, 22, 458-483.

(30) Hohwy, M.; Jakobsen, H. J.; Edén, M.; Levitt, M. H.; Nielsen,

N. C. J. Chem. Phys. 1998, 108, 2686-2694.

(31) Shantz, D. F.; Schmedt auf der Günne, J.; Koller, H.; Lobo, R. F. I. Am. Chem. Soc. 2000, 122, 6659-6663.

(32) Chan, J. C. C.; Eckert, H. J. Chem. Phys. 2001, 115, 6095-6105.

(33) Roming, M.; Feldmann, C.; Avadhut, Y. S.; Schmedt auf der Günne, J. Chem. Mater. 2008, 20, 5787-5795.

(34) Tessier, F.; Navrotsky, A.; Le Sauze, A.; Marchand, R. Chem. Mater. 2000, 12, 148-154.

(35) Sedlmaier, S. J.; Eberspächer, M.; Schnick, W. Z. Anorg. Allg. Chem. 2011, 637, 362-367.

(36) (a) Landskron, K. Ph.D. Thesis, Univ. Munich (LMU), 2001.

(b) Karau, F. Ph.D. Thesis, Univ. Munich (LMU), 2007.

(37) Sedlmaier, S. J.; Schmedt auf der Günne, J.; Schnick, W. Dalton Trans. 2009, 4081-4084.

(38) Brunner, E. J. Mol. Struct. 1995, 355, 61-85.

(39) Foster, M. D.; Treacy, M. M. J. A Database of Hypothetical Zeolite Structures: http://www.hypotheticalzeolites.net, accessed June 2010.

(40) McCusker, L. B.; Liebau, F.; Engelhardt, G. Pure Appl. Chem. 2001, 73, 381-394.

(41) Baerlocher, Ch.; McCusker, L. B. Database of Zeolites Structures: http://www.iza-structure.org/databases/, accessed November 2010.

(42) O'Keeffe, M.; Peskov, M. A.; Ramsden, S. J.; Yaghi, O. M. Acc. Chem. Res. 2008, 41, 1782-1789.

(43) Klee, W. E. Z. Kristallogr. 1987, 179, 67-76.

(44) Thimm, G.; Schumacher, S.; Uhr, W.; Klee, W. E. TOPOLAN, Topological Analysis of Crystal Structures; Univ. Karlsruhe: Germany, 1993.

(45) Brunner, G. O.; Meier, W. M. Nature 1989, 337, 146-147.

(46) Stock, N. Ph.D. Thesis, Univ. Bayreuth, 1998.

(47) Nardelli, M. Acta Crystallogr., Sect. C: Cryst. Struct. Commun. 1983, 39, 1141-1142.
(48) Cremer, D.; Pople, J. A. I.Am. Chem. Soc. 1975, 97, 1354-1358.

(49) Nardelli, M. PARST97, Univ. Parma: Italy, 1997.

(50) Karau, F. W.; Seyfarth, L.; Oeckler, O.; Senker, J.; Landskron, K.; Schnick, W. Chem.-Eur. I. 2007, 13, 6841-6852.

(51) Baerlocher, Ch.; Hepp, A.; Meier, W. M. Distance Least Squares Refinement Program, DLS-76; ETH: Zürich, 1977.

(52) Léger, J. M.; Haines, J.; Chateau, C.; Bocquillon, G.; Schmidt, M. W.; Hull, S.; Gorelli, F.; Lesauze, A.; Marchand, R. Phys. Chem. Miner. 2001, 28, 388-398.

(53) Shannon, R. D. Acta Crystallogr., Sect. A: Found. Crystallogr. 1976, 32, 751-767.

(54) Baur, W. H. Crystallogr. Rev. 1987, 1, 59-83.

(55) Zhu, W.; Kapteijn, F.; Moulijn, J. A.; den Exter, M. C.; Jansen, I. C. Langmuir 2000, 16, 3322-3329.

(56) Olson, D. H. U.S. Patent 6488 741, 2002.

(57) Olson, D. H.; Camblor, M. A.; Villaescusa, L. A.; Kuehl, G. H. Microporous Mesoporous Mater. 2004, 67, 27-33. 